\title{
PENGARUH BERBAGAI TAKARAN PUPUK NITROGEN TERHADAP PERTUMBUHAN DAN HASIL TANAMAN CAISIN VARIETAS SHINTA
}

\author{
Measuring Thr Effect Of Different Nintrogen Fertilizers On The Growth Of \\ Caisin Plant Variety Shinta
}

Suparman

Fakultas Pertanian, Universitas Winaya Mukti suparman@gmail.com

\begin{abstract}
The objective of this experiment was to study the effect nitrogen fertilizer dose on growth and yield of Caisin plant (Brassica junceae L.) var. Shinta. An experiment was carried out at Experimental Station of Agriculture Faculty of Winaya Mukti University at Tanjungsari-Sumedang, with the altitude about 850 m above sea level, from February 2015 up to March 2015. Experimental design used was a Randomized Block Design $(R B D)$, consisted of five treatment and each five replication. Dose of nitrogen $(N)$ fertilizer tested namely: $A=0 \mathrm{~kg} \mathrm{ha}{ }^{-1} \mathrm{~N}, B=10 \mathrm{~kg} \mathrm{ha}^{-1} \mathrm{~N}, C=20 \mathrm{~kg} \mathrm{ha}^{-1} \mathrm{~N}, D=30 \mathrm{~kg}$ $h a^{-1} N$, dan $E=40 \mathrm{~kg} \mathrm{ha}^{-1} \mathrm{~N}$. The result of this experiment showed that dose of nitrogen fertilizer be different influential on plant height at 28 Days After Planting (DAP) and 35 DAP, number of leaf at 35 DAP, weight of total dry matter per plant and weight of fresh per plant. Dose of nitrogen fertilizer $20 \mathrm{~kg} \mathrm{ha}^{-1}-30 \mathrm{~kg} \mathrm{ha}^{-1}$ give better effect on plant height at 28 Days After Planting (DAP) and 35 DAP, number of leaf at 35 DAP, weight of total dry matter per plant, and weight of fresh per plant. The optimum nitrogen fertilizer rate as much as $24.59 \mathrm{~kg} \mathrm{ha}^{-1}$ give a weight per plant caisin maximum of $76 .^{\mathrm{n} A}$ $g$.
\end{abstract}

Key Word : Nitrogen Fertilizer and Caisin

\section{PENDAHULUAN}

Tanah merupakan salah satu faktor penting untuk terlaksananya teknik budidaya yang baik. Bukan hanya tanah pupuk pun sangat berperan penting dalam pertumbuhan tanaman diantaranya pupuk Nitrogen $(\mathrm{N})$. Tanah sebagai media tumbuh tanaman mempunyai fungsi menyediakan air, udara dan unsur-unsur hara untuk pertumbuhan tanaman, namun demikian kemampuan tanah menyediakan unsur hara sangat terbatas. Hal ini terbukti dengan penggunaan tanah yang terus menerus secara intensif tanpa penambahan unsur hara mengakibatkan merosotnya produktivitas tanah, menurunkan hasil panen dan rusaknya sifat fisika, kimiawi dan biologi tanah (Hasibuan, 2006). 
Ketersediaan unsur hara yang dapat diserap oleh tanaman merupakan salah satu faktor yang dapat mempengaruhi tingkat hasil suatu tanaman. Macam dan jumlah unsur hara yang tersedia di dalam tanah bagi pertumbuhan tanaman pada dasarnya harus ada dalam keadaan yang cukup dan seimbang agar tingkat hasil yang diharapkan dapat tercapai dengan baik.

Unsur hara esensial yang dibutuhkan tanaman dari tanah adalah sebanyak 16 unsur, enam diantaranya digunakan dalam jumlah yang lebih besar yaitu $\mathrm{N}$, $\mathrm{P}, \mathrm{K}, \mathrm{Ca}, \mathrm{Mg}$ dan S. Ketersediaan dan keseimbangan unsur-unsur hara dalam tanah harus dipertahankan agar pertumbuhan dan hasil tanaman menjadi optimal.

Pemupukan pada tanaman caisin umumnya dilakukan dengan pemberian pupuk Urea, SP-36 dan KCl. Akan tetapi, tidak semua pupuk yang diberikan ke dalam tanah cepat tersedia bagi tanaman. Pada tanah yang mudah mengalami pencucian dan erosi, pupuk Urea akan lebih cepat larut sebelum digunakan oleh tanaman. Demikian pula fosfat yang diberikan dalam bentuk SP-36, sebagian akan terikat oleh kation $\mathrm{Al}$ dan Fe pada kemasaman tanah rendah atau terikat oleh kation $\mathrm{Ca}$ pada kemasaman tanah tinggi. Selain itu pula, penambahan unsur hara mikro seperti $\mathrm{Mg}, \mathrm{Fe}, \mathrm{Mn}, \mathrm{Zn}, \mathrm{Cu}, \mathrm{B}$ dan lainnya jarang diberikan melalui tanah sehingga tanaman menyerap unsur hara yang telah ada di dalam tanah. Tanpa adanya penambahan, unsur hara makro tentunya akan berkurang ketersediaannya, sehingga tanaman menjadi kekurangan unsur hara makro (Saifuddin Sarief, 1989).
Agar dapat tumbuh optimal tanaman caisin harus ditanam di lahan yang memiliki unsur hara makro dan mikro yang cukup tinggi dan kondisi tanah yang gembur, salah satu unsur hara makro yang sangat dibutuhkan oleh sayuran ini adalah unsur nitrogen, karena nitrogen merupakan unsur pokok pembentuk protein, asam nukleat, dan klorofil yang berguna dalam proses fotosintesis. Tanaman sayuran berdaun membutuhkan pupuk dengan unsur nitrogen yang cukup tinggi agar sayuran dapat tumbuh dengan baik, lebih renyah, segar dan enak dimakan. Hal ini sejalan dengan hasil penelitian Mahanani (2003) pada sayuran daun pak-coy, bahwa penggunaan unsur hara $\mathrm{N}$ pada tanaman pak-coy dapat menambah zat hijau daun yang di gunakan untuk pembentukan asam amino dan protein. Pada tanaman pak-coy yang tidak diberi unsur hara $\mathrm{N}$ tanaman tetap kecil dan daun lebih cepat berubah menjadi kuning, karena $\mathrm{N}$ yang tersedia tidak cukup untuk membentuk protein dan klorofil sehingga menyebabkan kemampuan tanaman menjadi berkurang dan produksi karbohidratnya berkurang.

Adapun takaran nitrogen yang diberikan pada tanaman caisin yaitu 20 kg ha ${ }^{-1}$ (Rahmat Rukmana, 1994) memberikan kisaran produksi sekitar 20 $\mathrm{t} \mathrm{ha}^{-1}-50 \mathrm{t} \mathrm{ha}^{-1}$ dengan penanaman yang baik dan tidak terkena serangan hama atau penyakit.

Pemberian takaran pupuk nitrogen (N) yang berbeda akan mempengaruhi pertumbuhan dan hasil tanaman caisin yang berbeda pula. Oleh karena itu perlu dilakukan penelitian. 


\section{Hipotesis}

1. Takaran pupuk nitrogen yang berbeda akan memberikan pengaruh yang berbeda terhadap pertumbuhan dan hasil tanaman caisin varietas Shinta.

2. Terdapat takaran pupuk nitrogen optimum yang memberikan hasil bobot segar tanaman caisin yang maksimum.

\section{METODE PENELITIAN}

Metode yang digunakan dalam penelitian ini adalah metode eksperimen dengan melaksanakan percobaan pada polybag di lapangan yaitu di kebun percobaan Fakultas Pertanian Universitas Winaya Mukti, Tanjungsari Sumedang, ketinggian tempat 830 meter di atas permukaan laut. Percobaan dilaksanakan dari bulan Februari 2015 sampai dengan bulan Maret 2015.

Bahan yang digunakan dalam percobaan ini adalah benih caisin varietas shinta, media tanam tanah ordo Andisol Tanjungsari dari lapisan olah sedalam $0-20 \mathrm{~cm}$, pupuk kandang domba, Urea $(45 \% \mathrm{~N})$, SP-36 (36\% $\left.\mathrm{P}_{2} \mathrm{O}_{5}\right), \mathrm{KCl}\left(60 \% \mathrm{~K}_{2} \mathrm{O}\right)$, Furadan $3 \mathrm{G}$, Fungisida Explore 250 EC, Insektisida Demolis dan polybag ukuran $40 \mathrm{~cm}$ x 40 $\mathrm{cm}$.

Rancangan yang digunakan adalah Rancangan Acak Kelompok (RAK), terdiri atas lima perlakuan dan masingmasing diulang lima kali. Takaran pupuk nitrogen $(\mathrm{N})$ yang diuji yaitu : A $=0 \mathrm{~kg} \mathrm{ha}^{-1} \mathrm{~N}, \mathrm{~B}=10 \mathrm{~kg} \mathrm{ha}^{-1} \mathrm{~N}, \mathrm{C}=20$ $\mathrm{kg} \mathrm{ha}^{-1} \mathrm{~N}, \mathrm{D}=30 \mathrm{~kg} \mathrm{ha}^{-1} \mathrm{~N}$, dan $\mathrm{E}=40$ $\mathrm{kg} \mathrm{ha}^{-1} \mathrm{~N}$.

Perlakuan tersebut masing-masing ditempatkan secara acak pada setiap ulangan. Jumlah tanaman per plot percobaan adalah 10 tanaman/polybag, tetapi yang digunakan sebagai tanaman sampel untuk pengamatan hanya 3 tanaman.

Rancangan respons ini terdiri dari pengamatan penunjang dan pengamatan utama. Pengamatan penunjang meliputi hasil analisis tanah sebelum percobaan, gulma serta serangan hama dan penyakit. Pengamatan utama adalah pengamatan yang datanya diuji secara statistik meliputi : tinggi tanaman dan jumlah daun (diamati pada umur 14 HST, 21 HST, 28 HST,dan 35 HST), bobot segar caisin per tanaman dan bobot kering total (biomas) per tanaman diamati setelah panen. Data hasil pengamatan diuji dengan analisis ragam (uji Fisher) untuk mengetahui ada tidaknya keragaman akibat pengaruh perlakuan yang dicoba dan dilanjutkan uji lanjutan dengan Uji DMRT pada taraf nyata $5 \%$. Untuk mengetahui takaran pupuk nitrogen optimum yang memberikan hasil bobot segar per tanaman caisin maksimum dilakukan analisis dengan menggunakan uji regresi kuadratik.

\section{HASIL DAN PEMBAHASAN}

Berdasarkan hasil analisis kesuburan tanah sebelum percobaan, ternyata tekstur tanah adalah lempung berliat dengan $\mathrm{pH}$ tanah sebesar 5,90 yang termasuk ke dalam katagori agak masam, sehingga untuk pertumbuhan caisin tanah ini cocok untuk dijadikan media budidaya caisin. Kandungan Corganik sedang yaitu $2,72 \%$ dengan $\mathrm{N}$ total sedang yaitu $0,29 \%$ dan $\mathrm{C} / \mathrm{N}$ adalah 13 . 
Kandungan $\mathrm{P}_{2} \mathrm{O}_{5}$-cadangan, $\mathrm{K}_{2} \mathrm{O}$ cadangan dan $\mathrm{P}_{2} \mathrm{O}_{5}$-tersedia Olsen adalah masing-masing tergolong rendah. Kation dapat ditukar seperti $\mathrm{Ca}, \mathrm{Mg}, \mathrm{K}$, dan $\mathrm{Na}$ termasuk sangat rendah sampai rendah. Kapasitas tukar kation (KTK) tergolong rendah, sedangkan kejenuhan basa (KB) termasuk sangat rendah. Berdasarkan data hasil analisis kesuburan tanah tersebut, maka diperoleh gambaran umum bahwa tingkat kesuburan tanah percobaan tergolong relatif kurang subur. Jika dilihat dari tingkat pengolahannya, maka tanah ini termasuk yang mudah diolah.

Hama yang menyerang caisin adalah belalang. Namun akibat yang ditimbulkan oleh hama ini tidak begitu mengganggu pertumbuhan dan perkembangan tanaman. Belalang hanya menimbulkan kerusakan pada daun caisin dengan meninggalkan bekas gigitan. Tingkat seragam hama belalang sangat rendah.

Gulma yang banyak tumbuh di petak percobaan pada polybag adalah dari golongan teki-tekian yaitu Cyperus rotundus. Kehadiran gulma dipertanaman dikendalikan melalui penyiangan, karena gulma dapat menyebabkan pertumbuhan dan hasil tanaman caisin kurang baik, yang diakibatkan adanya persaingan antara tanaman dengan gulma dalam hal ketersediaan unsur hara, ruang tumbuh dan cahaya matahari. Hal ini sesuai dengan pendapat yang dikemukakan oleh Edison Purba (2009) bahwa gulma dapat mengganggu, karena bersaing dengan tanaman utama terhadap kebutuhan sumberdaya (resources) yang sama yaitu unsur hara, air, cahaya, dan ruang tumbuh. Sebagai akibat dari persaingan tersebut produksi tanaman menjadi tidak optimal atau dengan kata lain ada kehilangan hasil dari potensi hasil yang dimiliki tanaman. Upaya pengendalian gulma tersebut adalah dilakukan penyiangan dengan cara mencabut gulma menggunakan tangan pada tanaman caisin umur 14 dan 21 hari setelah tanam, sehingga pertumbuhan dan perkembangan tanaman caisin tidak terganggu.

\section{Pengamatan Utama}

Pada Tabel 1 ternyata bahwa pemberian takaran pupuk nitrogen $(\mathrm{N})$ yang berbeda memberikan pengaruh yang berbeda tidak nyata terhadap tinggi tanaman pada umur 14 HST dan 21 HST, sedangkan pada umur 28 HST dan 35 HST pemberian takaran pupuk $\mathrm{N}$ mempelihatkan pengaruhnya terhadap tinggi tanaman. Pada pengamatan tinggi tanaman umur 28 HST pemberian pupuk $\mathrm{N}$ dengan takaran $20 \mathrm{~kg} \mathrm{ha}^{-1}$ dan $30 \mathrm{~kg}$ $\mathrm{ha}^{-1}$ memberikan pengaruh yang berbeda nyata dibandingkan dengan tanpa pemberian pupuk nitrogen $(\mathrm{N}=0 \mathrm{~kg}$ ha ${ }^{1}$ ), namun dengan pemberian pupuk $\mathrm{N}$ sebanyak $10 \mathrm{~kg} \mathrm{ha}^{-1}$ dan $40 \mathrm{~kg} \mathrm{ha}^{-1}$ berbeda tidak nyata. Pada tinggi tanaman umur 35 HST pemberian pupuk $\mathrm{N}$ sebanyak $10 \mathrm{~kg} \mathrm{ha}^{-1}, 20 \mathrm{~kg} \mathrm{ha}^{-1}, 30$ $\mathrm{kg} \mathrm{ha}{ }^{-1}$ dan $40 \mathrm{~kg} \mathrm{ha}^{-1}$ memberikan pengaruh yang berbeda nyata dibandingkan dengan tanpa pemberian pupuk nitrogen (0 $\mathrm{kg} \mathrm{ha} \mathrm{ha}^{-1}$, namun semua perlakuan tersebut berbeda tidak nyata terhadap tinggi tanaman. 
Berdasarkan hasil analisis ragam dan hasil uji lanjutan dengan Uji Jarak Berganda Duncan untuk jumlah daun seperti tersaji pada Tabel 2. Dari Tabel 2 terlihat bahwa takaran nitrogen $(\mathrm{N})$ yang berbeda memberikan pengaruh yang berbeda tidak nyata terhadap jumlah daun pada umur 14 HST, 21 HST dan 28 HST, sedangkan pada umur 35 HST pemberian takaran pupuk $\mathrm{N}$ mempelihatkan pengaruhnya terhadap jumlah daun, yaitu pemberian pupuk $\mathrm{N}$ sebanyak $30 \mathrm{~kg} \mathrm{ha}^{-1}$ memperlihatkan jumlah daun yang lebih tinggi dan berbeda nyata dibandingkan dengan tanpa pemberian pupuk nitrogen $(\mathrm{N}=0$ $\mathrm{kg} \mathrm{ha}^{-1}$ ) dan $10 \mathrm{~kg} \mathrm{ha}^{-1}$, tetapi dengan perlakuan pupuk nitrogen sebanyak 20 $\mathrm{kg} \mathrm{ha}^{-1}$ dan $40 \mathrm{~kg} \mathrm{ha}^{-1}$ berbeda tidak nyata terhadap jumlah daun.

Tabel 1. Pengaruh Berbagai Takaran Pupuk Nitrogen terhadap Tinggi Tanaman Umur 14 HST, 21 HST, 28 HST dan 35 HST

\begin{tabular}{|c|c|c|c|c|c|c|}
\hline \multirow{2}{*}{ Perlakuan } & \multicolumn{6}{|c|}{ Rata-rata Tinggi Tanaman pada Umur } \\
\hline & 14 HST & $21 \mathrm{H}$ & & $28 \mathrm{H}^{3}$ & & $35 \mathrm{HST}$ \\
\hline Pupuk Nitogen $(\mathrm{N})$ : & \multicolumn{6}{|c|}{ - } \\
\hline $\mathrm{A}\left(\mathrm{N}=0 \mathrm{~kg} \mathrm{ha}^{-1}\right)$ & 3,79 & 4,40 & a & 13,20 & a & 19,07 \\
\hline $\mathrm{B}\left(\mathrm{N}=10 \mathrm{~kg} \mathrm{ha}^{-1}\right)$ & 3,59 & 4,66 & a & 15,63 & $\mathrm{ab}$ & 24,63 \\
\hline $\mathrm{C}\left(\mathrm{N}=20 \mathrm{~kg} \mathrm{ha}^{-1}\right)$ & 4,13 & 5,06 & a & 16,80 & $\mathrm{~b}$ & 27,66 \\
\hline $\mathrm{D}\left(\mathrm{N}=30 \mathrm{~kg} \mathrm{ha}^{-1}\right)$ & 4,72 & 5,32 & a & 17,40 & $\mathrm{~b}$ & 27,19 \\
\hline $\mathrm{E}\left(\mathrm{N}=40 \mathrm{~kg} \mathrm{ha}^{-1}\right)$ & 4,13 & 4,80 & $\mathrm{a}$ & 15,73 & $\mathrm{ab}$ & 26,26 \\
\hline
\end{tabular}

Tabel 2. Pengaruh Berbagai Takaran Pupuk Nitrogen terhadap Jumlah Daun Umur 14 HST, 21 HST, 28 HST dan 35 HST

\begin{tabular}{|c|c|c|c|c|c|c|c|}
\hline \multirow{2}{*}{ Perlakuan } & \multicolumn{7}{|c|}{ Rata-rata Jumlah Daun pada Umur } \\
\hline & 14 HST & \multicolumn{2}{|c|}{$21 \mathrm{HST}$} & \multicolumn{2}{|c|}{$28 \mathrm{HST}$} & \multicolumn{2}{|c|}{35 HST } \\
\hline Pupuk Nitogen $(\mathrm{N})$ : & ---- & & & & & & \\
\hline $\mathrm{A}\left(\mathrm{N}=0 \mathrm{~kg} \mathrm{ha}^{-1}\right)$ & 2,07 & 2,80 & a & 3,73 & a & 5,80 & a \\
\hline $\mathrm{B}\left(\mathrm{N}=10 \mathrm{~kg} \mathrm{ha}^{-1}\right)$ & 2,13 & 2,80 & a & 4,20 & $\mathrm{a}$ & 6,06 & $a b$ \\
\hline $\mathrm{C}\left(\mathrm{N}=20 \mathrm{~kg} \mathrm{ha}^{-1}\right)$ & 2,00 & 3,33 & a & 4,46 & a & 6,80 & $a b c$ \\
\hline $\mathrm{D}\left(\mathrm{N}=30 \mathrm{~kg} \mathrm{ha}^{-1}\right)$ & 2,20 & 3,00 & $\mathrm{a}$ & 4,40 & a & 7,40 & $\mathrm{c}$ \\
\hline $\mathrm{E}\left(\mathrm{N}=40 \mathrm{~kg} \mathrm{ha}^{-1}\right)$ & 2,07 & 2,79 & a & 4,06 & a & 6,73 & $a b c$ \\
\hline
\end{tabular}


Berdasarkan hasil analisis dan uji lanjutan pada Tabel 1 dan 2 menunjukan bahwa pemberian takaran pupuk nitrogen $(\mathrm{N})$ yang berbeda memberikan pengaruh yang berbeda tidak nyata terhadap tinggi tanaman umur 14 HST dan 21 HST, jumlah daun umur 14 HST, 21 HST dan 28 HST. Hal ini diduga bahwa pada saat awal pertumbuhan tanaman lebih banyak dipengaruhi oleh sifat genetisnya daripada lingkungannya, sehingga pada tinggi tanaman maupun jumlah daun belum kelihatan pengaruhnya dari pemberian pupuk nitrogen tersebut, dan diduga tanaman caisin pada saat itu masih mampu memanfaat $\mathrm{N}$ yang ada pada tanaman tersebut, ini sesuai dengan pendapat Saifuddin Sarief (1989) bahwa efesiensi penyerapan unsur hara nitrogen tergantung juga umur tanaman serta dengan pemberian berbagai takaran belum banyak berpengaruh pada tanaman yang masih muda. Selanjutnya Subhan (1992) menyatakan bahwa penyerapan $\mathrm{N}$ sangat tergantung pertumbuhan organ tanaman terutama akar. Selain itu juga bahwa hasil analisis tanah sebelum percobaan menunjukkan bahwa kandungan $\mathrm{N}$ totalnya sedang, sehingga pemberian takaran $\mathrm{N}$ yang berbeda tidak memperlihatkan pengaruhnya pada awal-awal pertumbuhan.

Dari Tabel 1 dan 2, pengamatan tinggi tanaman umur 28 HST dan 35 HST dan jumlah daun umur 35 HST, pemberian pupuk nitrogen dengan takaran $20 \mathrm{~kg} \mathrm{ha}^{-1}$ sampai $30 \mathrm{~kg} \mathrm{ha}^{-1}$ mampu memperlihatkan tinggi tanaman dan jumlah daun yang lebih baik dibanding dengan takaran pupuk nitrogen yang lebih rendah dan yang lebih tinggi. Hal tersebut menunjukkan bahwa pemberian pupuk $\mathrm{N}$ baru nampak pengaruhnya pada tanaman yang umurnya sudah mulai dewasa, karena dengan pemberian pupuk $\mathrm{N}$ dapat memperbaiki pertumbuhan vegetatif dan pembentukan protein tanaman (Sarwono Hardjowigeno, 2003). Selain itu bahwa pemberian pupuk nitrogen yang berbeda akan memberikan sumbangan unsur hara yang berbeda pula pada media tanam, sehingga nitrogen akan mempengaruhi terhadap pertumbuhan vegetatif tanaman, juga dapat mempengaruhi penyerapan unsur hara lainnya oleh tanaman (Buckman and Brady, 1982).

Dalam proses fotosintesis, tanaman tidak lepas kaitannya dengan klorofil pada daun, sedangkan klorofil juga tidak lepas kaitannya dengan protein, karena protein adalah sebagai penyusun klorofil. Keadaan protein di dalam tanaman sangat dipengaruhi oleh ketersediaan $\mathrm{N}$ di dalam tanah (Nurhajati Hakim, dkk., 1986). Selanjutnya Saifuddin Sarief (1989) menyatakan bahwa apabila unsur hara nitrogen yang tersedia lebih banyak daripada unsur lainnya, dapat dihasilkan protein yang lebih banyak pula dan daun dapat tumbuh lebih lebar sebagai akibat proses fotosintesis lebih banyak, selain itu jumlah nitogen yang cukup dapat meningkatkan protoplasma, bertambah besarnya ukuran dan jumlah sel yang mengakibatkan jumlah daun dan tinggi tanaman meningkat. 
Berdasarkan hasil analisis ragam dan hasil uji lanjutan dengan Uji Jarak Berganda Duncan untuk bobot kering total (biomas) tanaman caisin seperti yang tertera pada Tabel 3 menunjukkan bahwa pemberian takaran nitrogen $(\mathrm{N})$ yang berbeda memberikan pengaruh yang berbeda nyata terhadap bobot kering total. Pemberian takaran pupuk $\mathrm{N}$ sebanyak $20 \mathrm{~kg} \mathrm{ha}^{-1}, 30 \mathrm{~kg} \mathrm{ha}^{-1}$ dan 40 $\mathrm{kg} \mathrm{ha}^{-1}$ mempelihatkan bobot kering total yang lebih berat dan berbeda nyata dibandingkan dengan tanpa pemberian pupuk nitrogen $\left(0 \mathrm{~kg} \mathrm{ha}^{-1}\right)$, tetapi dengan perlakuan pupuk nitrogen sebanyak 10 $\mathrm{kg} \mathrm{ha}^{-1}$ berbeda tidak nyata.
Berdasarkan hasil analisis ragam dan hasil uji lanjutan dengan Uji Jarak Berganda Duncan untuk bobot segar tanaman caisin seperti yang terlihat pada Tabel 4. Dari Tabel 4 menunjukkan bahwa takaran nitrogen (N) yang berbeda memberikan pengaruh yang berbeda nyata terhadap bobot segar. Pemberian takaran pupuk N sebanyak 20 $\mathrm{kg} \mathrm{ha}^{-1}$ mempelihatkan bobot segar yang lebih berat dan berbeda nyata dengan tanpa pemberian pupuk nitrogen $(0 \mathrm{~kg}$ $\mathrm{ha}^{-1}$ ) dan $10 \mathrm{~kg} \mathrm{ha}^{-1}$, tetapi dengan perlakuan pupuk nitrogen sebanyak 30 $\mathrm{kg} \mathrm{ha}{ }^{-1}$ dan $40 \mathrm{~kg} \mathrm{ha}^{-1}$ berbeda tidak nyata.

Tabel 3. Pengaruh Berbagai Takaran Pupuk Nitrogen terhadap Bobot Kering Total (Biomas) Tanaman Caisin

\begin{tabular}{lc}
\hline \multicolumn{1}{c}{ Perlakuan } & $\begin{array}{c}\text { Rata-rata } \\
\text { Bobot Kering Total (Biomas) } \\
\text { Tanaman Caisin }\end{array}$ \\
\hline Takaran Pupuk Nitogen $(\mathrm{N}):$ & $0,91 \mathrm{a}$ \\
$\mathrm{A}\left(\mathrm{N}=0 \mathrm{~kg} \mathrm{ha}^{-1}\right)$ & $2,22 \mathrm{ab}$ \\
$\mathrm{B}\left(\mathrm{N}=10 \mathrm{~kg} \mathrm{ha}^{-1}\right)$ & $4,17 \mathrm{~b}$ \\
$\mathrm{C}\left(\mathrm{N}=20 \mathrm{~kg} \mathrm{ha}^{-1}\right)$ & $3,70 \mathrm{~b}$ \\
$\mathrm{D}\left(\mathrm{N}=30 \mathrm{~kg} \mathrm{ha}^{-1}\right)$ & $3,61 \mathrm{~b}$ \\
$\mathrm{E}\left(\mathrm{N}=40 \mathrm{~kg} \mathrm{ha}^{-1}\right)$ & \\
\hline
\end{tabular}

Tabel 4. Pengaruh Berbagai Takaran Pupuk Nitrogen terhadap Bobot Segar Tanaman Caisin

\begin{tabular}{lc}
\hline \multicolumn{1}{c}{ Perlakuan } & Rata-rata Bobot Segar Tanaman Caisin \\
\hline Takaran Pupuk Nitogen $(\mathrm{N}):$ & $27,66 \mathrm{a}$ \\
$\mathrm{A}\left(\mathrm{N}=0 \mathrm{~kg} \mathrm{ha}^{-1}\right)$ & $57,13 \mathrm{~b}$ \\
$\mathrm{~B}\left(\mathrm{~N}=10 \mathrm{~kg} \mathrm{ha}^{-1}\right)$ & $77,53 \mathrm{~d}$ \\
$\mathrm{C}\left(\mathrm{N}=20 \mathrm{~kg} \mathrm{ha}^{-1}\right)$ & $71,20 \mathrm{c}$ \\
$\mathrm{D}\left(\mathrm{N}=30 \mathrm{~kg} \mathrm{ha}^{-1}\right)$ & $57,60 \mathrm{~b}$ \\
$\mathrm{E}\left(\mathrm{N}=40 \mathrm{~kg} \mathrm{ha}^{-1}\right)$ &
\end{tabular}


Berdasarkan hasil analisis ragam dan hasil uji lanjutan dengan Uji Jarak Berganda Duncan untuk bobot segar tanaman caisin seperti yang terlihat pada Tabel 4. Dari Tabel 4 menunjukkan bahwa takaran nitrogen (N) yang berbeda memberikan pengaruh yang berbeda nyata terhadap bobot segar. Pemberian takaran pupuk N sebanyak 20 $\mathrm{kg} \mathrm{ha}^{-1}$ mempelihatkan bobot segar yang lebih berat dan berbeda nyata dengan tanpa pemberian pupuk nitrogen $(0 \mathrm{~kg}$ $\mathrm{ha}^{-1}$ ) dan $10 \mathrm{~kg} \mathrm{ha}^{-1}$, tetapi dengan perlakuan pupuk nitrogen sebanyak 30 $\mathrm{kg} \mathrm{ha}^{-1}$ dan $40 \mathrm{~kg} \mathrm{ha}^{-1}$ berbeda tidak nyata.

Perlakuan pupuk $\mathrm{N}$ dengan takaran antara $20 \mathrm{~kg} \mathrm{ha}^{-1}$ sampai $30 \mathrm{~kg} \mathrm{ha}^{-1}$ bobot segar per tanaman dan bobot kering total per tanaman yang lebih tinggi dibandingkan perlakuan lainnya. Hal ini diduga karena pada takaran pupuk $\mathrm{N}$ tersebut dapat diserap secara efektif oleh tanaman menjelang pertumbuhan akhir (menjelang panen) seperti halnya pada tinggi tanaman umur 28 HST dan 35 HST serta jumlah daun umur 35 HST. Keadaan ini sejalan dengan pendapat Dwidjoseputro (1988) bahwa dengan hadirnya unsur hara $\mathrm{N}$ yang cukup, maka proses fotosintesis berjalan baik. Fotosintesis dengan bantuan cahaya matahari dan klorofil daun dapat merubah zat anorganik menjadi zat organik yaitu karbohidrat, dan karbohidrat yang terbentuk ini merupakan bahan dasar untuk penyusun bahan organik lainnya yang dibutuhkan tanaman. Selanjutnya Sri Setyati Harjadi (1979) menyatakan bahwa karbohidrat hasil fotosintesis sebagian besar ditranslokasikan ke bagian tanaman yang membutuhkannya atau ke daerah penimbunan yang akhirnya akan mendorong pembelahan sel lebih banyak, sehingga proses pertumbuhan dan perkembangan tanaman juga akan berjalan lebih cepat. Hal ini sangat berpengaruh terhadap bobot segar per tanaman dan bobot kering total per tanaman.

Untuk mengetahui pemberian takaran pupuk nitrogen (X) optimum yang dapat memberikan bobot segar per tanaman caisin (Y) yang maksimun, dilakukan analisis regresi kuadratik dengan hasil analisis ragam regresi yang teruji nyata dan kesesuaian model yang sesuai dengan persamaam regresi sebagai berikut :

$$
\hat{Y}=27,3132+3,9642 X-0,08062
$$

$\mathrm{X}^{2}$, dari persamaan tersebut memberikan nilai duga bobot segar per tanaman caisin maksimum sebesar 76,04 g dengan pemberian takaran pupuk nitrogen optimum sebanyak $24,59 \mathrm{~kg}$ ha 1 dan nilai koefsien determinasi $\left(\mathrm{R}^{2}\right)$ sebesar 0,9201 (92,01\%). Takaran optimum pupuk nitrogen untuk menghasilkan bobot segar per tanaman caisin yang maksimum berada pada kisaran taraf perlakuan pupuk nitrogen $20 \mathrm{~kg} \mathrm{ha}^{-1}$ sampai $30 \mathrm{~kg} \mathrm{ha}^{-1}$. Adapun kurva regresi kuadratik hubungan antara bobot segar per tanaman caisin dengan takaran pupuk nitrogen disajikan pada Gambar 1.

Pada Gambar 1 terlihat bahwa jika takaran pupuk nitrogen lebih ditingkatkan lagi dari takaran optimum, maka bobot segar per tanaman caisin yang dihasilkan cenderung menurun 


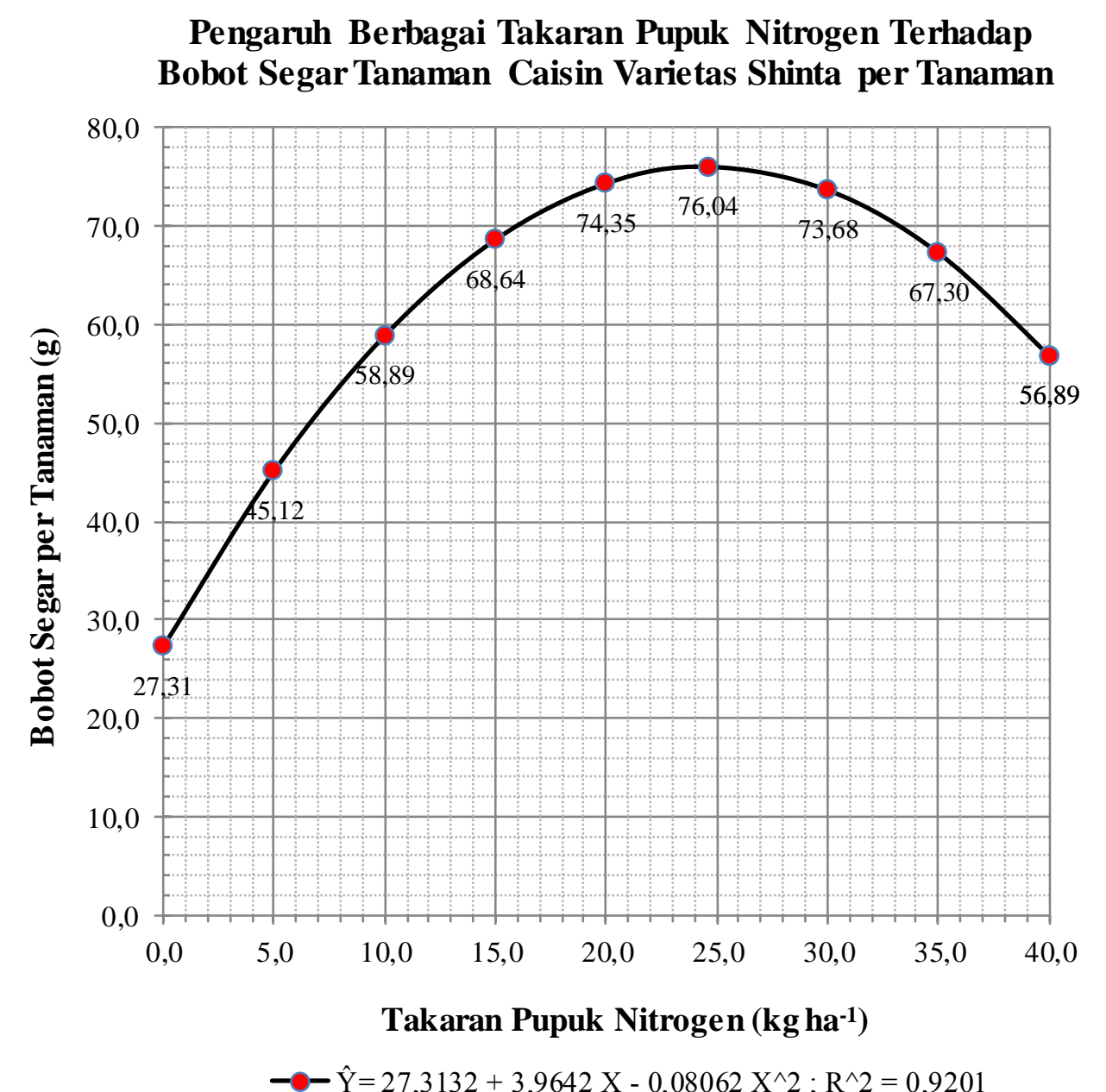

Gambar 1. Kurva Regresi Kuadratik Hubungan Antara Bobot Segar per Tanaman Caisin dengan Pemberian Takaran Pupuk Nitrogen

Hal tersebut diduga semakin banyaknya unsur hara yang tersedia di dalam tanah terutama unsur hara makro nitrogen, maka akan terjadi ketidak seimbangan unsur hara yang diserap oleh tanaman, bahkan untuk unsur hara mikro jika serapannya berlebihan bisa menampakan gejala keracunan bagi tanaman yang selanjutnya dapat menurunkan hasil. Hal tersebut sesuai dengan formulasi dari Mitcherlich
(1954) dikutip Marschner (1986), yang lebih dikenal dengan pernyataan hukum peningkatan pasokan hara yang dapat menurunkan hasil (low of diminishing yield increment), artinya jika pasokan salah satu unsur hara terus meningkat sementara unsur hara lainnya tetap, maka hasil akan menurun karena unsur hara pada tanah dalam keadaan tidak seimbang. 


\section{KESIMPULAN}

Berdasarkan hasil percobaan dan pembahasan dapat ditarik kesimpulan sebagai berikut :

1. Takaran pupuk nitrogen yang berbeda berpengaruh terhadap tinggi tanaman umur 28 HST dan 35 HST, jumlah daun umur 35 HST, bobot kering total dan bobot segar per tanaman caisin.

2. Pemberian pupuk nitrogen sebanyak $20 \mathrm{~kg} \mathrm{ha}^{-1}$ sampai $30 \mathrm{~kg}$ $\mathrm{ha}^{-1}$ memberikan tinggi tanaman umur 28 HST dan 35 HST, jumlah daun umur 35 HST, dan bobot kering total yang lebih baik. Takaran pupuk nitrogen optimum sebanyak 24,59 $\mathrm{kg} \mathrm{ha}^{-1}$ memberikan bobot segar per tanaman caisin maksimum sebanyak 76,04 g.

\section{DAFTAR PUSTAKA}

Bambang Cahyono. 2003. Teknik dan Budidaya Sawi Hijau (Pai-Tsai). Yayasan Penebar Nusantara, Yogyakarta.

Buckman, H. O. and Nyle C. Brady. 1982. Ilmu Tanah. Terjemahan Soegiman. Penerbit Bhatara Karya Aksara, Jakarta.

Dwidjoseputro. 1988. Pengantar Fisiologi Tumbuhan. P. T. Gramedia Pustaka Utama, Jakarta

Eko Haryanto, Estu Rahayu, dan Tina Suhartini. 1994. Sawi dan Selada. Penebar Swadaya, Depok.
Firlana. 2010. Tanggap Pertumbuhan Tanaman Sawi (Brassica Juncea L.) Varietas Tosakan Terhadap Pemberian Berbagai Dosis Pupuk Urea Dan TSP.

Kartasapoetra., A. G. dan M. M. Sutedjo. 2000. Pupuk dan Cara Pemupukannya. Rineka Cipta, Jakarta.

Margiyanto, Eko. 2008. Budidaya Tanaman

Sawi.http://zuldesains.wordpres s.com /2008/01/11/budidayatanaman-sawi/. (27 Juni 2013).

Mahanani, C. R. L 2003. Pengaruh Media Tanam dan Pupuk NPK terhadap Produki Tanaman Pak-choi (Brassica chinensis) Varietas green choi. Fakultas Per Jurusan Buhuma Pertanian. Institut Pertanian Bogor.

Marschner, H. 1986. Mineral Nutrition of Higher Plant. Academic Press Inc., London Ltd., Orlando, New York.

Mengel, K. and E. A. Kirkby. 1979. Principles of Plants Nutrition. International Potash Institute. Berne, Switzerland.

Nurhajati Hakim, M. Yusuf Nyakpa, A. M. Lubis, Sutopo Ghani Nugroho, M. Amin Diha, Go Ban Hong, H. H. Bailey. 1986. Dasar-dasar Ilmu Tanah. Penerbit Universitas Lampung, Bandar Lampung.

Rioardi . 2009. Pupuk Nitrogen. $\underline{\mathrm{http}: / / \text { rioardi.wordpress.com,200 }}$ 
Rahmat Rukmana. 1994. Bertanam Petsai dan Sawi. Penerbit Kanisius. Yogyakarta.

Rahmat Rukmana. 2008. Kubis Bunga dan Broccoli. Penerbit Kanisius, Yogyakarta.

Rubatzky, V. E. dan M. Yamaguchi, 1995. Sayuran Dunia. ITBPress, Bandung.

Saifuddin Sarief. 1989. Kesuburan dan Pemupukan Tanah Pertanian. Pustaka Buana, Bandung.

Sarwono Hardjowigeno. 2003. Ilmu Tanah. Akademika Pressindo, Jakarta.

Sri Setyati Harjadi. 1979. Pengantar Agronomi. P. T. Gramedia, Jakarta.

Subekti. 2009. Morfologi Tanaman dan Fase Pertumbuhan Sawi. http://balitsereal.litbang.deptan. go.id/bjagung/e patpdf. (03 Mei 2009).

Subhan. 1992. Pengaruh Jenis Tanah dan Dosis Pupuk N terhadap Pertumbuhan serta Hasil Tanaman Petsai Kultivar Eikun. Dalam Buletin Peneliyian Hortikultura. Volume XXIII No. 3. Tahun 1992. Balai Penelitian Hortikultura Lembang, Bandung. Hal. 16-19.

Tim Penulis PS. 1993. Sayur Komersil. Penebar Swadaya. Jakarta. 